\title{
Utilization of Reclaimed Asphalt Pavement Materials in Rigid Pavement
}

\author{
Priyanka Parashar \\ M.Tech. Scholar \\ Dept. of Civil Engineering \\ Jagan Nath University \\ Jaipur, India
}

\author{
Mukesh Choudhary \\ Assistant Professor \\ Dept. of Civil Engineering \\ Jagan Nath University \\ Jaipur, India
}

\author{
Dr.Bharat Nagar \\ Professor \& H.O.D. \\ Dept. of Civil Engineering \\ Jagan Nath University \\ Jaipur, India
}

\begin{abstract}
Concrete has proven to be a suitable and crucial material in construction and it also has been successfully implemented in numerous projects. Demand for concrete for construction is on the increase and at the same time, there is a shortage of natural aggregates in many areas. Today it has become really difficult to obtain natural aggregates for concrete locally. Bringing aggregate from faraway places increases the cost of concrete. Hence a real and urgent need to consider using satisfactory alternative aggregate materials. On the other hand, already a huge amount of industrial waste are generated around the world such as fly ash, blast furnace slag etc. Most of these industrial wastes are not effectively used, and a large part of reclaimed asphalt pavements (RAP) material are removed for reconstruction, resurfacing are disposed of in landfills. As the demand of power and amenities increases, the volume of these wastes would increase against this background, RAP concrete has begun to gain significant consideration from the research scholar and construction practitioners, because of its advantageous in using industrial by-product to replace cement and RAP aggregate replace natural aggregate.
\end{abstract}

Keywords: Rigid Pavement; Reclaimed Asphalt Pavement (RAP) \& RAP Aggregate, Economic Pavement.

\section{INTRODUCTION}

Through years of practice and experience, concrete has proven to be a suitable and crucial material in construction and it also has been successfully implemented in numerous projects. Demand for concrete for construction is on the increase and at the same time, there is a shortage of natural aggregates in many areas. Today it has become really difficult to obtain natural aggregates for concrete locally. Bringing aggregate from faraway places increases the cost of concrete. Hence a real and urgent need to consider using satisfactory alternative aggregate materials. The demand for construction materials such as crushed stone, river sand and gravel continues to rise while economic sources are often becoming limited

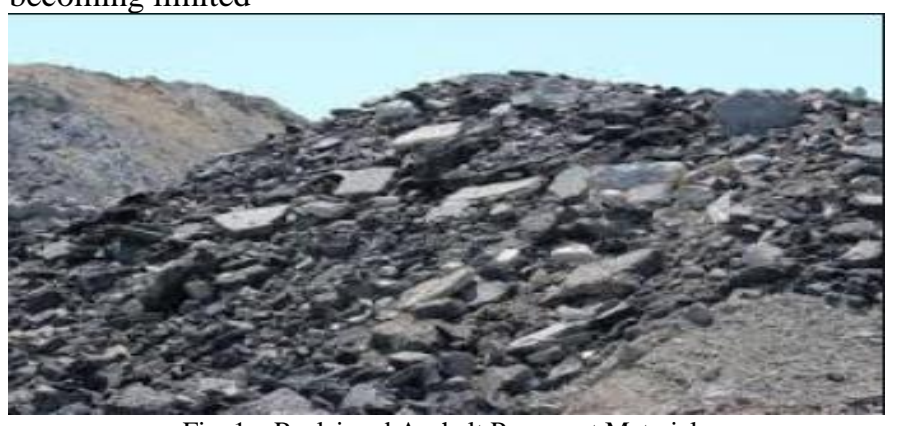

Fig. 1 - Reclaimed Asphalt Pavement Materia
To ensure that the best use is made of available materials, an overall materials utilization strategy must be developed that will be coupled with environmental and energy considerations. While recognizing the need for a unified strategy, a detailed study focuses on the utilization of reclaimed asphalt pavement (RAP) aggregate and industrial byproducts (fly ash) in construction is necessary. Increased usage of RAP aggregates and byproducts of the thermal power plant will both decrease the demand for available materials and solve the disposal problems. Recycling these materials not only eliminates and solves environmental problems caused by their disposal or burial but also reduces the consumption of natural basic materials and increases the lifespan of resources and mines.

\section{NEED OF STUDY}

India has the 2 nd biggest road network within the world with over 5.23 million $\mathrm{km}$ at the present, consisting of National Highways, Expressways, State Highways, Major District Roads, Other District Roads and Village Roads. More than $90 \%$ of Indian highways are of flexible pavements in which the majority have attained its service life. Demolition of the same generates a large quantity of inert waste that is either hauled off to the disposal site or stockpiled along the generation point. Besides the high transportation cost, it also requires huge land for disposal. This increases the burden on landfill facilities and results in being dumped at nearby farms. INDIA 's Ministry of Road Transport and Highways has decided to maneuver towards making rigid pavement the default mode of construction on national highways. The decision, taken after considering factors related to service life, fuel consumption, weather conditions, maintenance costs and natural resources, primarily aims to promote environmentally friendly construction practices in the execution of road projects. According to NAPA, the current annual U.S. production of latest asphalt pavement material is approximately 500 million tons per year, which incorporates about 60 million tons of reclaimed material that is reused or recycled directly into pavements. As of 2007, about 40 million tons of RAP is reused or recycled into other pavement-related applications per annum for a total use of over 100 million tons of RAP each year. Since most reclaimed asphalt is reused or recycled, asphalt pavement has the very best recycling rate by percentage among recycled materials. 
Aggregate makes up between 60 to $80 \%$ of the entire mass of the ultimate concrete product and as natural resources begin to diminish and become more expensive to procure there becomes a need to find alternative sources for the fine and coarse aggregates and RAP is a good alternative source for rigid pavement. Fly ash production in the thermal power plant is a very large volume. This causes a serious environmental problem. So, there is a need to develop technologies for the production of value-added products on a sustainable basis.

\section{SCOPE OF THE STUDY}

This research work presents a study of the effects of RAP and fly ash on the performance of the rigid pavement. Design mix was prepared and testing was performed in the laboratory to study the effect of RAP and fly ash on the mechanical and durability property of rigid pavement. The effect of with and without RAP aggregate to the design mix was determined. Finally, the results obtained from laboratory tests are analyzed.

\section{OBJECTIVE OF THE STUDY}

To review research finding on the RAP and current standard practices for using RAP in concrete.

$>$ To investigate the effect of aggregate gradation after adding RAP.

$>$ To find the concrete mix design with and without RAP.

$>$ To find the performance of the concrete with and without RAP.

\section{METHODOLOGY ADOPTED}

\section{$>$ TESTS OF RELIABILITY \& STRENGTH OF CONCRETE MATERIALS}

The strength of concrete depends on the quality of the material used. The properties of cement, natural coarse aggregates, fly ash, RAP and fine aggregate is tested. Cement is tested for fineness, specific gravity and initial \& final setting time. After gradation for aggregate as per MoRT\&H provisions, Optical Moisture Content is also calculated. Then RAP materials and fly ash is tested as per MoRT\&H provisions. thereafter the Concrete Mix is tested for slump value, compressive strength, split tensile $\&$ flexure strength after creating design mix of concrete (in place of virgin aggregates) with $20 \%$ RAP material \& fly ash of proportion $0 \%, 5 \%, 10 \% \& 15 \%$ respectively.

\section{> MIX DESIGN PROCEDURE OF RAP CONCRETE}

The property of the concrete produced depends on the property of the materials used. RAP aggregate is dense material and it absorbs less amount of water. The mix design calculations are dependent on the properties of the constituent materials. Concrete mix proportioning was carried out using the revised Indian Standards guidelines, as given by (BIS 10262 1982) and ("IRC-44 (2017)").

\section{EXPERIMENTAL INVESTIGATION ON STRENGTH \& DURABILITY CHARACTERISTIC OF RAP COCRETE}

The effect of incorporations of coarse RAP aggregates and fly ash on the fresh, mechanical and durability properties of concrete mixes was investigated.

\section{RESULTS}

\section{WORKABILITY TEST}

Mix design- concrete with $20 \%$ RAP and Replacement of Cement by Fly ash.

\begin{tabular}{|c|c|c|}
\hline Mix & Mix Name & Slump (mm) \\
\hline Mix 1 & 20\%RAP0\%FA & 16 \\
\hline Mix2 & 20\%RAP5\%FA & 19 \\
\hline Mix3 & 20\%RAP10\%FA & 21 \\
\hline Mix4 & 20\%RAP\%15FA & 24 \\
\hline
\end{tabular}

Table 1 Fresh Concrete Properties with RAP and Fly Ash

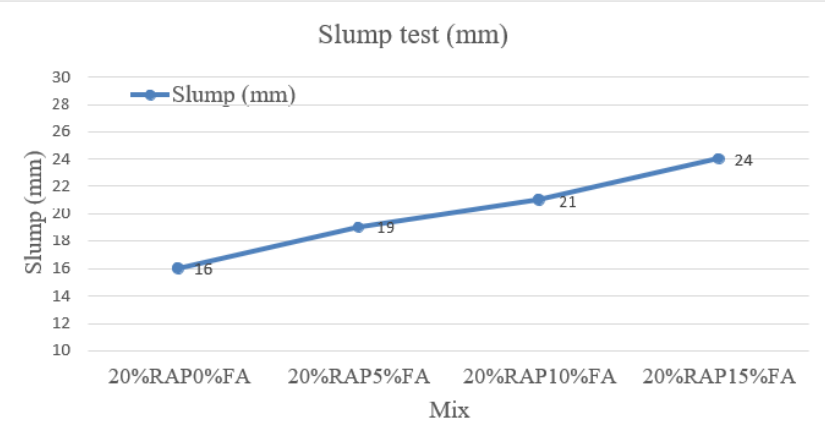

Fig. 1- Slump Test Graph of of Concrete with RAP And Fly Ash

\section{COMPRESSION STRENGTH TEST RESULTS}

In mix design cubes are cast and these cubes are tested in compressive strength testing machine in 7days, 14day and 28 days. Test result are as shown in Fig.2.

\begin{tabular}{|c|c|c|c|c|c|}
\hline \multirow{2}{*}{$\begin{array}{l}\text { S. } \\
\text { No. }\end{array}$} & \multirow{2}{*}{ Mix } & \multirow[t]{2}{*}{ Sample } & \multicolumn{3}{|c|}{$\begin{array}{c}\text { Compressive Strength } \\
(\mathrm{MPa})\end{array}$} \\
\hline & & & 7 day & 14 day & 28 day \\
\hline \multirow{4}{*}{1} & \multirow{4}{*}{$\begin{array}{c}\text { Mix } 1 \\
(20 \% \text { RAP0\%FA) }\end{array}$} & 1 & 31.36 & 40.22 & 45.07 \\
\hline & & 2 & 26.55 & 33.84 & 44.05 \\
\hline & & 3 & 29.85 & 37.25 & 44.87 \\
\hline & & Average & 29.25 & 37.10 & 44.66 \\
\hline \multirow{4}{*}{2} & \multirow{4}{*}{$\begin{array}{c}\text { Mix } 2 \\
(20 \% \text { RAP5\%FA) }\end{array}$} & 1 & 23.08 & 25.75 & 29.28 \\
\hline & & 2 & 25.64 & 27.14 & 31.24 \\
\hline & & 3 & 27.48 & 28.23 & 34.35 \\
\hline & & Average & 25.4 & 27.13 & 31.62 \\
\hline \multirow{4}{*}{3} & \multirow{4}{*}{$\begin{array}{c}\text { Mix } 3 \\
(20 \% \mathrm{RAP} 10 \% \mathrm{FA})\end{array}$} & 1 & 25.35 & 30.28 & 34.12 \\
\hline & & 2 & 26.94 & 29.27 & 32.59 \\
\hline & & 3 & 27.02 & 32.89 & 36.61 \\
\hline & & Average & 26.44 & 30.81 & 33.35 \\
\hline \multirow{4}{*}{4} & \multirow{4}{*}{$\begin{array}{c}\text { Mix } 4 \\
(20 \% \mathrm{RAP} 15 \% \mathrm{FA})\end{array}$} & 1 & 28.18 & 33.13 & 38.87 \\
\hline & & 2 & 23.63 & 31.22 & 40.16 \\
\hline & & 3 & 27.68 & 34.55 & 44.25 \\
\hline & & Average & 26.50 & 32.97 & 41.09 \\
\hline
\end{tabular}

Table 2 Compressive Strength of Mix Design 


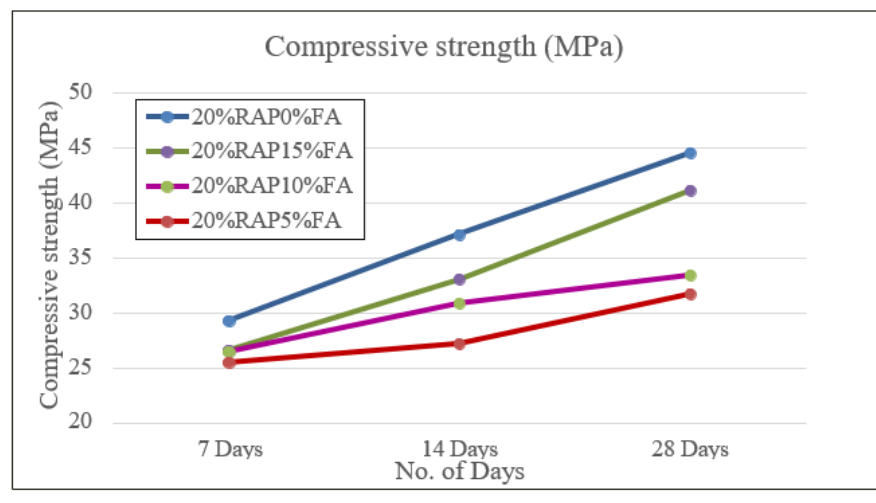

Fig. 2- Compressive Strength of Concrete with RAP And Fly Ash

\section{SPLIT TENSILE STRENGTH TEST}

Optimum Moisture Content for achiving maximum densidty of granular material is calculated by Modified Procter Test. Water content is added untill maximum density is achieved i.e.6.3\%. Curve for OMC is shown in Fig.3.

\begin{tabular}{|c|c|c|c|c|c|}
\hline \multirow{2}{*}{$\begin{array}{l}\text { S. } \\
\text { No. }\end{array}$} & \multirow{2}{*}{ Mix } & \multirow{2}{*}{ Sample } & \multicolumn{3}{|c|}{$\begin{array}{c}\text { Compressive Strength } \\
\text { (MPa) }\end{array}$} \\
\hline & & & 7 day & $\begin{array}{c}14 \\
\text { day }\end{array}$ & $\begin{array}{c}28 \\
\text { day }\end{array}$ \\
\hline \multirow{4}{*}{1} & \multirow{4}{*}{$\begin{array}{c}\text { Mix } 1 \\
\text { (20\%RAP0\%FA) }\end{array}$} & 1 & 2.01 & 2.21 & 3.64 \\
\hline & & 2 & 2.785 & 3.48 & 4.56 \\
\hline & & 3 & 3.01 & 4.56 & 5.33 \\
\hline & & Average & 2.60 & 3.52 & 4.51 \\
\hline \multirow{4}{*}{2} & \multirow{4}{*}{$\begin{array}{c}\text { Mix } 2 \\
(20 \% \text { RAP5\%FA) }\end{array}$} & 1 & 2.07 & 2.41 & 2.86 \\
\hline & & 2 & 2.25 & 2.58 & 3.21 \\
\hline & & 3 & 2.44 & 2.64 & 2.74 \\
\hline & & Average & 2.25 & 2.54 & 2.94 \\
\hline \multirow{4}{*}{3} & \multirow{4}{*}{$\begin{array}{c}\text { Mix } 3 \\
\text { (20\%RAP10\%FA) }\end{array}$} & 1 & 1.95 & 2.31 & 2.95 \\
\hline & & 2 & 2.33 & 3.04 & 3.09 \\
\hline & & 3 & 2.25 & 2.79 & 3.51 \\
\hline & & Average & 2.18 & 2.71 & 3.18 \\
\hline \multirow{4}{*}{4} & \multirow{4}{*}{$\begin{array}{c}\text { Mix } 4 \\
\text { (20\%RAP15\%FA) }\end{array}$} & 1 & 2.06 & 2.52 & 2.83 \\
\hline & & 2 & 2.21 & 2.90 & 3.61 \\
\hline & & 3 & 2.86 & 3.21 & 3.56 \\
\hline & & Average & 2.38 & 2.87 & 3.33 \\
\hline
\end{tabular}

Table 3 Split Tensile Strength of Mix Design

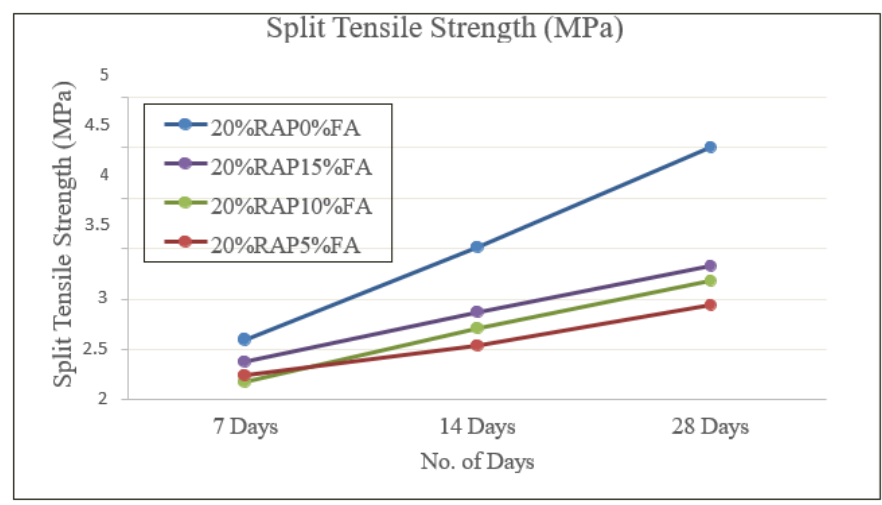

Fig. 3 - Split Tensile Strength of Concrete with RAP And Fly Ash

\section{FLEXURAL STRENGTH TEST}

\begin{tabular}{|c|c|c|c|c|}
\hline \multirow{2}{*}{$\begin{array}{l}\text { S. } \\
\text { No. }\end{array}$} & \multirow{2}{*}{ Mix } & \multirow{2}{*}{ Sample } & \multicolumn{2}{|c|}{$\begin{array}{c}\text { Compressive Strength } \\
\text { (MPa) }\end{array}$} \\
\hline & & & 14 day & 28 day \\
\hline \multirow{3}{*}{1} & \multirow{3}{*}{$\begin{array}{c}\text { Mix } 1 \\
\text { (20\%RAP0\%FA) }\end{array}$} & 1 & 5.50 & 7.17 \\
\hline & & 2 & 5.02 & 5.38 \\
\hline & & Average & 5.26 & 6.28 \\
\hline \multirow{3}{*}{2} & \multirow{3}{*}{$\begin{array}{c}\text { Mix } 2 \\
(20 \% \text { RAP5\%FA) }\end{array}$} & 1 & 3.76 & 4.47 \\
\hline & & 2 & 4.68 & 5.25 \\
\hline & & Average & 4.22 & 4.86 \\
\hline \multirow{3}{*}{3} & \multirow{3}{*}{$\begin{array}{c}\text { Mix } 3 \\
(20 \% \text { RAP10\%FA) }\end{array}$} & 1 & 3.87 & 4.51 \\
\hline & & 2 & 4.99 & 5.73 \\
\hline & & Average & 4.43 & 5.12 \\
\hline \multirow{3}{*}{4} & \multirow{3}{*}{$\begin{array}{c}\text { Mix } 4 \\
\text { (20\%RAP15\%FA) }\end{array}$} & 1 & 3.98 & 4.56 \\
\hline & & 2 & 5.14 & 5.91 \\
\hline & & Average & 4.56 & 5.23 \\
\hline
\end{tabular}

Table 4 Flexural Strength of Mix Design

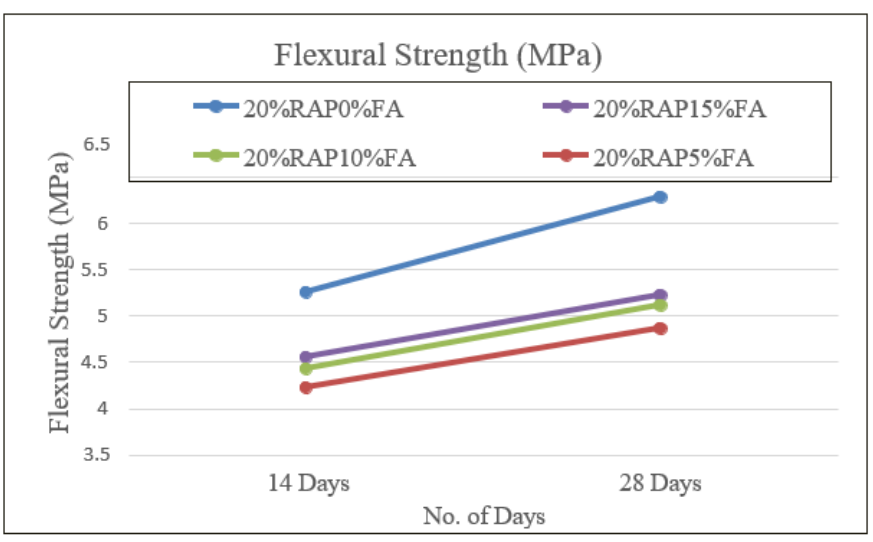

Fig. 4- Flexural Strength of Concrete with RAP And Fly Ash

\section{ULTRASONIC PULSE VELOCITY TEST}

\begin{tabular}{|c|c|c|c|c|c|c|}
\hline Mix & $\begin{array}{l}\text { Sam } \\
\text { ple } \\
\text { No. }\end{array}$ & $\begin{array}{c}\text { Dist } \\
\text { ance } \\
\text { bet } \\
\text { wee } \\
\text { n } \\
\text { Tra } \\
\text { nsd } \\
\text { ucer } \\
\text { s } \\
\text { (m } \\
\text { m) } \\
\end{array}$ & $\begin{array}{c}\text { Time } \\
(\mu \mathrm{s})\end{array}$ & $\begin{array}{c}\text { Veloci } \\
\text { ty } \\
(\mathbf{m} / \mathbf{s})\end{array}$ & $\begin{array}{c}\text { Quality of } \\
\text { Cocrete }\end{array}$ & \\
\hline \multirow{4}{*}{$\begin{array}{l}\text { Mix } 1 \\
(20 \% \\
\text { RAP0 } \\
\% \text { FA) }\end{array}$} & 1 & 150 & 33.3 & 4504 & Very good & \\
\hline & 2 & 150 & 34.1 & 4399 & Very good & \\
\hline & 3 & 150 & 34.4 & 4360 & Very good & \\
\hline & \multicolumn{2}{|c|}{ Averege } & 33.93 & 4421 & Very good & \\
\hline \multirow{4}{*}{$\begin{array}{l}\text { Mix } 2 \\
(20 \% \\
\text { RAP5 } \\
\% \text { FA) }\end{array}$} & 1 & 150 & 34.9 & 4301 & Very good & \\
\hline & 2 & 150 & 38.9 & 3853 & Good & \\
\hline & 3 & 150 & 42.5 & 3528 & Good & \\
\hline & \multicolumn{2}{|c|}{ Averege } & 38.77 & 3894 & Good & \\
\hline \multirow{4}{*}{$\begin{array}{c}\text { Mix } 3 \\
\text { (20\% } \\
\text { RAP1 } \\
0 \% F \\
\text { A) }\end{array}$} & 1 & 150 & 33.9 & 4424 & Very good & \\
\hline & 2 & 150 & 34.3 & 4373 & Very good & \\
\hline & 3 & 150 & 34.8 & 4310 & Very good & \\
\hline & \multicolumn{2}{|c|}{ Averege } & 34.33 & 4369 & Very good & \\
\hline \multirow{4}{*}{$\begin{array}{c}\text { Mix } 4 \\
(20 \% \\
\text { RAP1 } \\
5 \% \mathrm{~F} \\
\text { A) }\end{array}$} & 1 & 150 & 34.9 & 4287 & Very good & \\
\hline & 2 & 150 & 34.6 & 4325 & Very good & \\
\hline & 3 & 150 & 34.2 & 4388 & Very good & \\
\hline & \multicolumn{2}{|c|}{ Averege } & 34.57 & 4333 & Very good & Very good \\
\hline
\end{tabular}

Table 5 Ultrasonic Pulse Velocity 


\section{CONCLUSIONS}

From above study it is seen that RAP (Reclaimed Asphalt Pavement) Aggregate in rigid pavement with fly ash can provide many technical benefits and it would also be fair to say provide many environmental and expected cost benefits. The study has shown that, regardless of original concrete type or strength, reclaimed asphalt pavement materials aggregates can be generated when asphalt pavements are removed for reconstruction, resurfacing, or to obtain access to buried utilities. Clearly, this information could more utilization of RAP for using in rigid pavement, while reducing disposal to land fill. Total permeable voids in concrete mixes were found to increase with the increase in the coarse RAP proportions. However, less than $20 \%$ increase was observed for RAP mixes. In reclaimed asphalt pavement (RAP) used in rigid pavement with, compressive strength decreases for $10 \%$, $30 \%, 40 \%, 50 \%$ of RAP are $10.75 \%, 4.02 \%, 10.62 \%, 38.42 \%$ and compressive strength increases for $20 \%$ RAP are $22.70 \%$. Fly ash mix with reclaimed asphalt pavement used in rigid pavement, workability increased. Because the shape of fly ash particles is spherical. Its act like miniature ball bearing within concrete mix, thus provide lubricant effect. Pumpability of concrete also improve by reducing friction losses. When replacing cement with fly ash in the concrete with $20 \%$ RAP, 28 days compressive strength is slightly lower than the control mix. It increases with increasing the fly ash content. For $5 \%, 10 \%, 15 \%$ of fly ash, compressive strength decreases $29.19 \%, 25.31 \%, 8 \%$. Most optimum being $15 \%$ of fly ash replacement. Split tensile strength and flexural strength in Fly ash - RAP concrete in rigid pavement has shown similar trend as in development of compressive strength.

\section{REFERENCES}

[1] Abdel-Mohti, A., Shen, H., and Khodair, Y. (2016). "Characteristics of self-consolidating concrete with RAP and SCM." Construction and Building Materials, Elsevier Ltd, $102,564-573$.

[2] Abraham, S. M., and Ransinchung, G. D. R. N. (2018). "Influence of RAP aggregates on strength, durability and porosity of cement mortar." Construction and Building Materials, 189, 1105-1112.

[3] BIS:2386 part III-1963, R. 2002. (2002). "Method of Test for aggregate for concrete, Part III Specific gravity, density, voids, absorption and bulking." Bureau of Indian Standards, New Dehli.

[4] BIS:5816-1999, R. 2004. (2004). "Splitting tensile strength of concrete." Bureau of Indian Standards, New Dehli.

[5] Delwar, M., F. M. and R. T. (1997). (2018). "'Use of Reclaimed Asphalt Pavement as an Aggregate in Portland cement Concrete', ACI Materials Journal, 94(3):251. 8. Solanki, P., Zaman." Resources, Conservation and Recycling, Elsevier, 133(October 2017), 30-49.

[6] Huang, B., Shu, X., and Li, G. (2005). "Laboratory investigation of portland cement concrete containing recycled asphalt pavements." Cement and Concrete Research, 35(10), 2008-2013.

[7] "IRC-44 (2017)" Guidelines for cement concrete mix design for pavements.

[8] IS:2386 (Part-1). (1963). "Method of Test for aggregate for concrete." Bureau of Indian Standards, New Delhi.

[9] IS 456:2000. (2000). Plain and Reinforced Concrete Code of Practice. Indian Standard.

[10] Singh, S., Ransinchung, G. D., and Kumar, P. (2017). "Effect of mineral admixtures on fresh, mechanical and durability properties of RAP inclusive concrete." Construction and Building Materials, Elsevier Ltd, 156, 19-27.

[11] Hossiney, N., Tia, M., and Bergin, M. J. (2010). "Concrete containing RAP for use in concrete pavement." International Journal of Pavement Research and Technology, 3(5), 251-258.

[12] IS: 3812 (Part-1). (2003). "286Pulverized fuel ash — specification. Part 1: For use as Pozzolana in cement, Cement Mortar and Concrete (Second Revision)." Bureau of Indian Standards.

[13] IS 8112. (2013). "Ordinary Portland Cement, 43 Grade Specification.” Bureau of Indian Standards.

[14] Pranshoo Solanki, B. D. (2015). "Mechanical Properties of Concrete Containing Recycled Asphalt Pavement and Class C Fly Ash." 2015 World of Coal Ash (WOCA) Conference in Nasvhille.

[15] Specification for Road and Bridge works, fifth revision. (2013). "Ministry of road transport and highway (MORTH)." 